\title{
Myc is required for $\beta$-catenin-mediated mammary stem cell amplification and tumorigenesis
}

\author{
Mejdi Moumen ${ }^{1,2+}$, Aurélie Chiche ${ }^{1,2+}$, Charles Decraene ${ }^{2,3}$, Valérie Petit ${ }^{1,2}$, Alberto Gandarillas ${ }^{4,5}$, \\ Marie-Ange Deugnier ${ }^{1,2}$, Marina A Glukhova ${ }^{1,2^{*}}$ and Marisa M Faraldo ${ }^{1,2^{*}}$
}

\begin{abstract}
Background: Basal-like breast cancer is a heterogeneous disease characterized by the expression of basal cell markers, no estrogen or progesterone receptor expression and a lack of HER2 ov erexpression. Recent studies have linked activation of the Wnt/ $\beta$-catenin pathway, and its downstream target, Myc, to basal-like breast cancer. Transgenic mice $\mathrm{K} 5 \Delta \mathrm{N} \beta \mathrm{cat}$ previously generated by our team present a constitutive activation of Wnt/ $\beta$-catenin signaling in the basal myoepithelial cell layer, resulting in focal mammary hyperplasias that progress to invasive carcinomas. Mammary lesions developed by $\mathrm{K} 5 \Delta \mathrm{N} \beta$ cat mice consist essentially of basal epithelial cells that, in contrast to mammary myoepithelium, do not express smooth muscle markers.
\end{abstract}

Methods: Microarray analysis was used to compare $\mathrm{K} 5 \Delta \mathrm{N} \beta \mathrm{cat}$ mouse tumors to human breast tumors, mammary cancer cell lines and the tumors developed in other mouse models. Cre-Lox approach was employed to delete Myc from the mammary basal cell layer of $\mathrm{K} 5 \Delta \mathrm{N} \beta$ cat mice. Stem cell amplification in $\mathrm{K} 5 \Delta \mathrm{N} \beta$ cat mouse mammary epithelium was assessed with 3D-culture and transplantation assays.

Results: Histological and microarray analyses of the mammary lesions of $\mathrm{K} 5 \Delta N \beta c a t$ females revealed their high similarity to a subset of basal-like human breast tumors with squamous differentiation. As in human basal-like carcinomas, the Myc pathway appeared to be activated in the mammary lesions of K5 $\Delta N \beta$ cat mice. We found that a basal cell population with stem/progenitor characteristics was amplified in $\mathrm{K} 5 \Delta \mathrm{N} \beta \mathrm{cat}$ mouse preneoplastic glands. Finally, the deletion of Myc from the mammary basal layer of $\mathrm{K} 5 \Delta \mathrm{N} \beta \mathrm{cat}$ mice not only abolished the regenerative capacity of basal epithelial cells, but, in addition, completely prevented the tumorigenesis.

Conclusions: These results strongly indicate that $\beta$-catenin-induced stem cell amplification and tumorigenesis rely ultimately on the Myc pathway activation and reinforce the hypothesis that basal stem/progenitor cells may be at the origin of a subset of basal-like breast tumors.

Keywords: $\beta$-catenin signaling, Mammary gland, Myc, Stem cells, Basal-like breast cancer

\section{Introduction}

Microarray gene expression profiling of human primary breast tumors has identified five main cancer subtypes: luminal $\mathrm{A}$ and $\mathrm{B}, \mathrm{Her}-2+$, basal-like and normal-like [1-3]. In the last years, additional molecular subtypes have emerged including claudin-low and apocrine tumors $[4,5]$. The basal-like subtype, accounts for 15 to $20 \%$ of all breast cancers and is characterized by the

\footnotetext{
*Correspondence: marina.glukhova@curie.fr; maria-luisa.martin-faraldo@curie.fr ${ }^{\dagger}$ Equal contributors

${ }^{1}$ Institut Curie, Centre de Recherche, F-75248 Paris, France

${ }^{2}$ CNRS, UMR144, F-75248 Paris, France

Full list of author information is available at the end of the article
}

expression of mammary basal cell markers, such as keratins 5 and 14 (K5 and K14 respectively) and the transcription factor p63. Basal-like tumors often exhibit poor differentiation and higher rates of proliferation and are frequently assimilated to triple-negative tumors, as neither express estrogen receptors (ER) nor progesterone receptors and both lack HER2 overexpression [1]. Metaplastic carcinomas, characterized by the differentiation of cancer cells towards squamous epithelium or mesenchymal elements, form part of the spectrum of basal-like tumors [6].

The transcription factor proto-oncogene Myc regulates the expression of many genes involved in the control of

\section{Biomed Central}


cellular metabolism, growth and proliferation [7]. Myc overexpression due to gene amplification or transcriptional regulation is commonly associated with human cancer. In breast cancer, Myc deregulation is associated with poor outcome [8] and recent studies have shown that Myc expression is particularly elevated in the basallike (or triple-negative) subtype [9-11]. Myc is a transcriptional target of the $\mathrm{Wnt} / \beta$-catenin, and activation of the $\mathrm{Wnt} / \beta$-catenin signaling pathway has been linked to basal-like breast cancer $[12,13]$.

The mammary epithelium consists of two layers: luminal secretory cells and basal myoepithelial cells. During lactation, luminal cells produce and secrete milk in response to hormone stimulation. In addition to the above mentioned basal epithelial markers, myoepithelial cells express smooth muscle (SM) contractile proteins, such as $\alpha$-SM-actin and SM-myosin. Various studies in human and mouse models have suggested that multipotent stem cells capable of regenerating the mammary epithelium upon transplantation reside in the basal myoepithelial layer [14-16]. Unipotent lineage-restricted stem/progenitor cells have recently been identified by a lineage-tracing approach $[17,18]$. Although the mechanisms controlling the functions of mammary stem cells currently are understood only partly, several studies have pointed to Wnt/ $\beta$-catenin pathway. First, Wnt factors have been shown to promote the self-renewal of mouse mammary epithelial cells capable of gland regeneration [19]. In addition, adult uni- and bipotent stem cells responsive to $\mathrm{Wnt} / \beta$-catenin signaling have recently been described [17]. In human mammary epithelial cells, activation of the Wnt/ $\beta$-catenin pathway after PTEN knockdown has been shown to induce the amplification of the stem/progenitor compartment [20].

It remains largely unknown how Wnt/ $\beta$-catenin signaling promotes mammary stem cell expansion. A recent study has revealed that a Wnt target, the G-proteincoupled receptor Lrg5, is necessary for mammary stem cell activity [21]. We have shown that another Wnt/ $\beta$ catenin target, Myc, is essential for mammary stem cell function in normal adult gland homeostasis [22]. However, it remains unknown, if Myc is required for mammary stem cell amplification and tumorigenesis driven by $\beta$-catenin, or, other effectors of Wnt/ $\beta$-catenin signaling pathway can substitute for Myc in the control of mammary stem cell expansion and development of malignant breast lesions. Here, we address this question using a genetic approach. The transgenic $\mathrm{K} 5 \Delta \mathrm{N} \beta$ cat mice generated by our team display a constitutive activation of $\mathrm{Wnt} / \beta$-catenin signaling due to the expression of a stabilized form of $\beta$-catenin in the mammary basal cell layer and develop mammary lesions resembling basal-like mammary carcinomas [23]. We show here that the stem cell pool is amplified in the preneoplastic glands of $\mathrm{K} 5 \Delta \mathrm{N} \beta \mathrm{cat}$ mice. Furthermore, we found that Myc is required for this amplification and for $\beta$-catenin-induced tumorigenesis.

\section{Results}

Constitutive activation of $\beta$ - catenin signaling in mammary basal cells induces triple-negative tumors

Female $\mathrm{K} 5 \Delta \mathrm{N} \beta$ cat mice develop mammary tumors with a median latency of 10 to 11 months [23]. Focal ductal hyperplasias, visible at early stages, progress to carcinomas, often presenting areas of squamous differentiation (Figure 1A). The tumors are highly proliferative and consist of cells positive for basal markers, including K5, K14 and p63, but negative for the smooth muscle proteins characteristic of myoepithelial cells, such as $\alpha$-SMA and calponin (Figure 1B, Additional file 1: Figure S1A). These tumors stain negative for estrogen and progesterone receptors (ER and PR; Figure 1C,D). Moderate levels of ErbB2 were detected, but not higher than those found in normal tissue (Additional file 1: Figure S1B).

Affymetrix microarray gene expression analyses of $\mathrm{K} 5 \Delta \mathrm{N} \beta$ cat mouse mammary tumors and hyperplasias confirmed their basal characteristics, with an upregulation of basal genes and downregulation of luminal and smooth muscle genes. Quantitative RT-PCR (qPCR) analyses confirmed the upregulation of basal markers, such as Krt14, Trp63, Trp73, Cdh3 and Bcn, and downregulation of the luminal genes Krt18, Esr1, Prlr and the smooth muscle marker, Acta2, with respect to control tissue (Figure 1E).

We performed a hierarchical clustering analysis of control and $K 5 \Delta \mathrm{N} \beta$ cat mice datasets with a previously established basal gene signature [24]. We identified three distinct sample groups, corresponding to normal tissue, hyperplasia and tumors (Figure 1F). Most of the basal genes investigated were upregulated in the mammary tumors of $\mathrm{K} 5 \Delta \mathrm{N} \beta$ cat mice, whereas luminal genes were downregulated. Moreover, a combined hierarchical clustering analysis of our $\mathrm{K} 5 \Delta \mathrm{N} \beta$ cat dataset and datasets for human breast cancer cell lines [25] or basal breast tumors [26] showed a clustering of $K 5 \Delta \mathrm{N} \beta$ cat tumors with the basal breast cancer lines and basal-like breast tumors (Additional file 2: Figure S2).

Altogether these results indicate that the constitutive activation of $\beta$-catenin signaling in the mammary basal cell layer induces tumors with gene expression profiles similar to that of basal-like human breast carcinomas and morphological similarities to malignant metaplastic human breast lesions.

\section{Myc is required for the formation of $\mathrm{K} 5 \Delta \mathrm{N} \beta$ cat tumors}

Several previously identified $\beta$-catenin target genes, including $M y c$, were upregulated in $\mathrm{K} 5 \Delta \mathrm{N} \beta$ cat tumors, as shown by microarray and qPCR analyses (Figure 2B; Additional file 3: Figure S3A). Of note, the expression of 

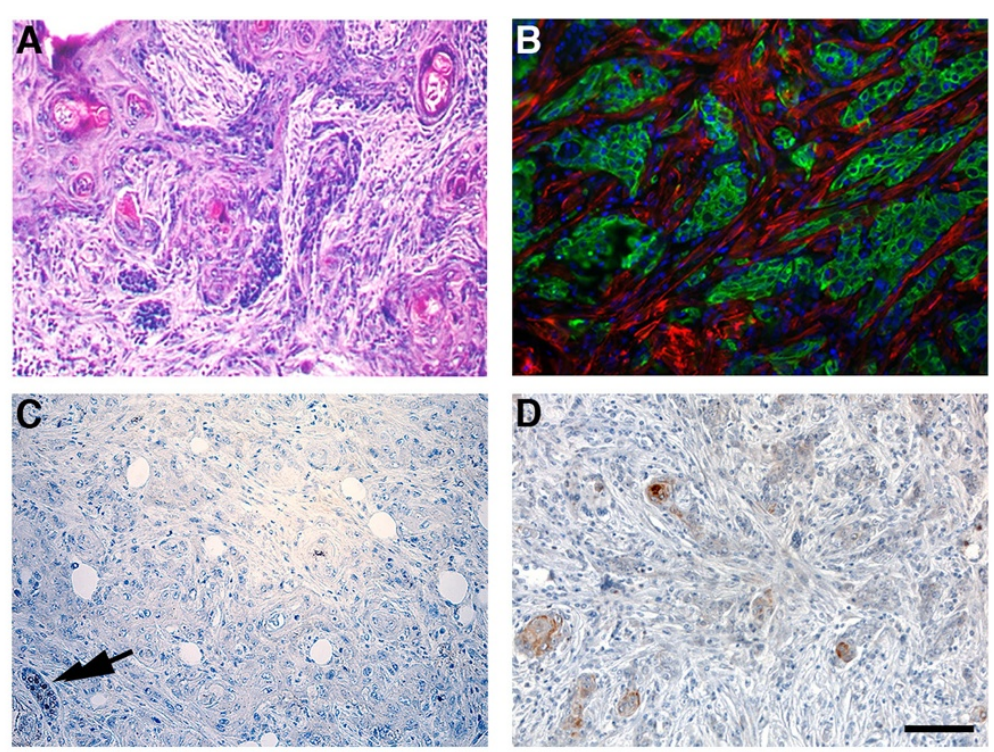

E
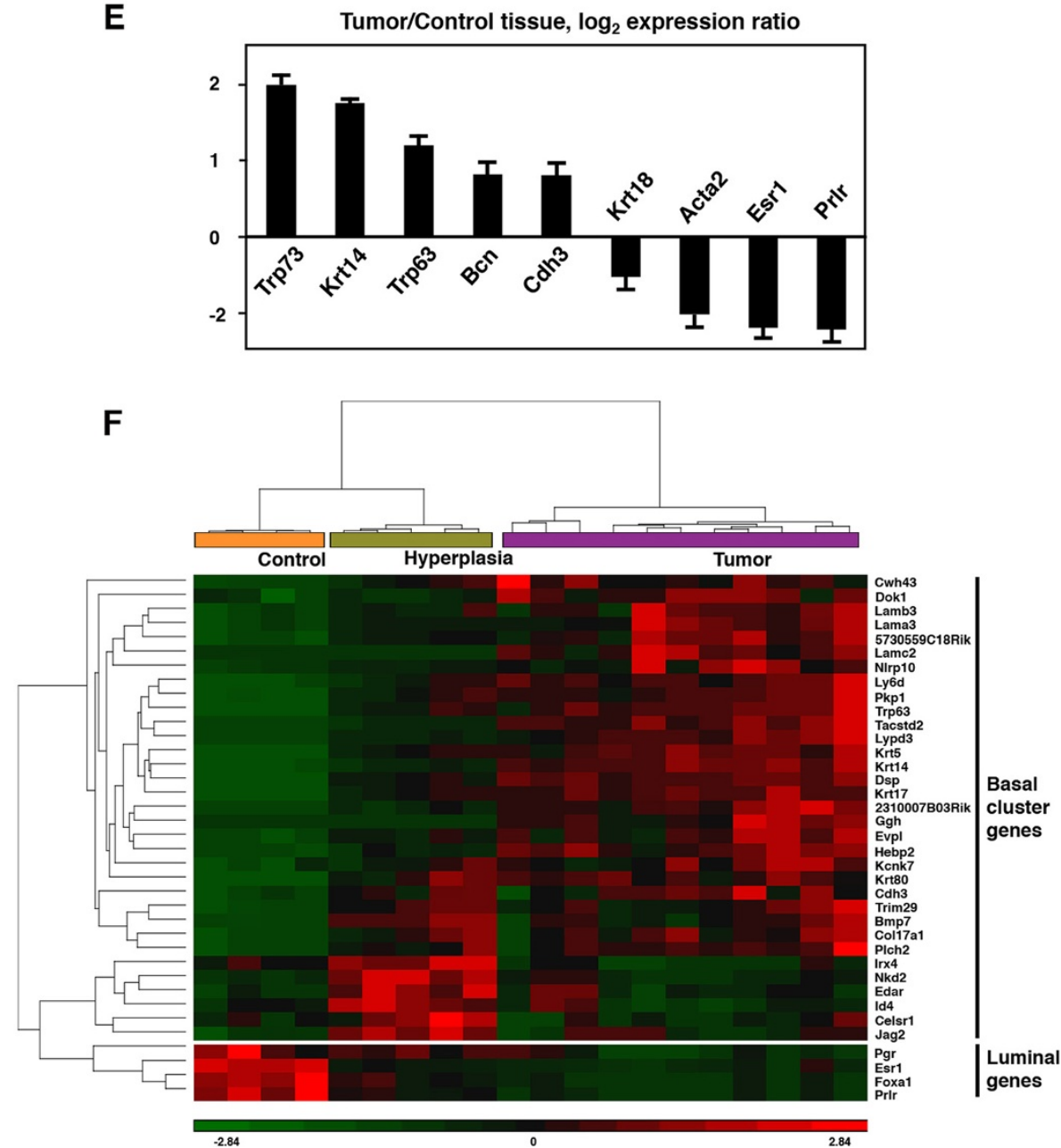

Figure 1 (See legend on next page.) 
(See figure on previous page.)

Figure $1 \mathrm{~K} 5 \Delta \mathrm{N} \beta$ cat mammary tumors display characteristics of basal-like tumors. A. Haematoxylin/eosin staining. B. Double immunofluorescence analysis with anti-K5 (green) and anti a-SMA (red) antibodies; nuclei are stained with DAPI. C, D. Immunohistochemistry with anti-ER (C) and anti-PR (D) antibodies. Arrow in $\mathbf{C}$ indicates the presence of normal ductal luminal cells positively stained for ER. Bar: $75 \mu \mathrm{m}$ (B,C), $150 \mu \mathrm{m}(\mathbf{A}, \mathbf{D})$. E. qPCR analysis of representative basal and luminal genes. The graph shows mean values \pm SEM for four control tissue and five $\mathrm{K} 5 \Delta \mathrm{N} \beta$ cat tumor samples; $p<0.05$. F. Cluster analysis of $\mathrm{K} 5 \Delta \mathrm{N} \beta$ cat tumors, for the subset of genes defining the basal cluster in mouse tumor models (upper panel, [24]) and four luminal epithelial genes (lower panel). Data from 4 control mammary tissue, 5 hyperplasia and 11 tumor samples from K5 $\Delta \mathrm{N} \beta$ cat female are shown.

Cyclin D1, one of the first identified $\beta$-catenin targets, was not altered in tumor tissue (Additional file 3: Figure S3A). Ingenuity pathway analysis (IPA) of microarray data showed that the Myc pathway was activated in $\mathrm{K} 5 \Delta \mathrm{N} \beta \mathrm{cat}$ tumors (Additional file 3: Figure S3B). We found that Myc accumulated in the nuclei of tumor cells, often co-localizing with the HA-tagged transgenic protein (Figure 2A), and the upregulation of several Myc target genes in $\mathrm{K} 5 \Delta \mathrm{N}$ ßcat tumors was confirmed by qPCR (Figure 2B).

To study whether Myc contributed to $\mathrm{K} 5 \Delta \mathrm{N}$ ßcat mammary tumor formation, we conditionally deleted $M y c$ gene from the basal cell layer of $\mathrm{K} 5 \Delta \mathrm{N}$ ßcat mice by crossing them with mice carrying conditional alleles for $M y c\left(M y c^{F / F}\right)$ and K5Cre mice. Cohorts of $\mathrm{K} 5 \Delta \mathrm{N}$ $\beta$ cat, $\mathrm{K} 5 \Delta \mathrm{N} \beta \mathrm{cat}$; K5Cre; $M y c^{F /+}$ and $\mathrm{K} 5 \Delta \mathrm{N}$ ßcat; K5Cre; $M y c^{F / F}$ females were monitored for tumor formation until the age of 15 months (Figure 2C). In 90-95\% of $\mathrm{K} 5 \Delta \mathrm{N}$ ßcat females, palpable mammary tumors developed with a mean latency of 11 and 9.6 months for virgin and parous females, respectively. In contrast, only less than half of the females heterozygous for Myc in basal cells (K5 $\Delta \mathrm{N} \beta \mathrm{cat} ; \mathrm{K} 5 \mathrm{Cre} ; \mathrm{Myc}^{\mathrm{F} /+}$ ) developed tumors (Figure 2C). Furthermore, tumor latency was delayed (14 and 11.2 months for virgin and parous females respectively), and the number of tumors per animal was reduced, when compared to $\mathrm{K} 5 \Delta \mathrm{N} \beta$ cat females (Table 1).

Strikingly, regardless of parity, none of the females with Myc-deficient basal cells (K5 $\mathrm{N}$ ( 3 cat; K5Cre; $M y c^{\text {F/F }}$ ) developed palpable mammary tumors. Moreover, whole-mount mammary gland analysis revealed the absence of hyperplasia in $\mathrm{K} 5 \Delta \mathrm{N}$ ßcat; K5Cre; $M y c^{F / F}$ females (Figure 3A). Thus, Myc is required for mammary tumor formation in $\mathrm{K} 5 \Delta \mathrm{N} \beta$ cat mice.
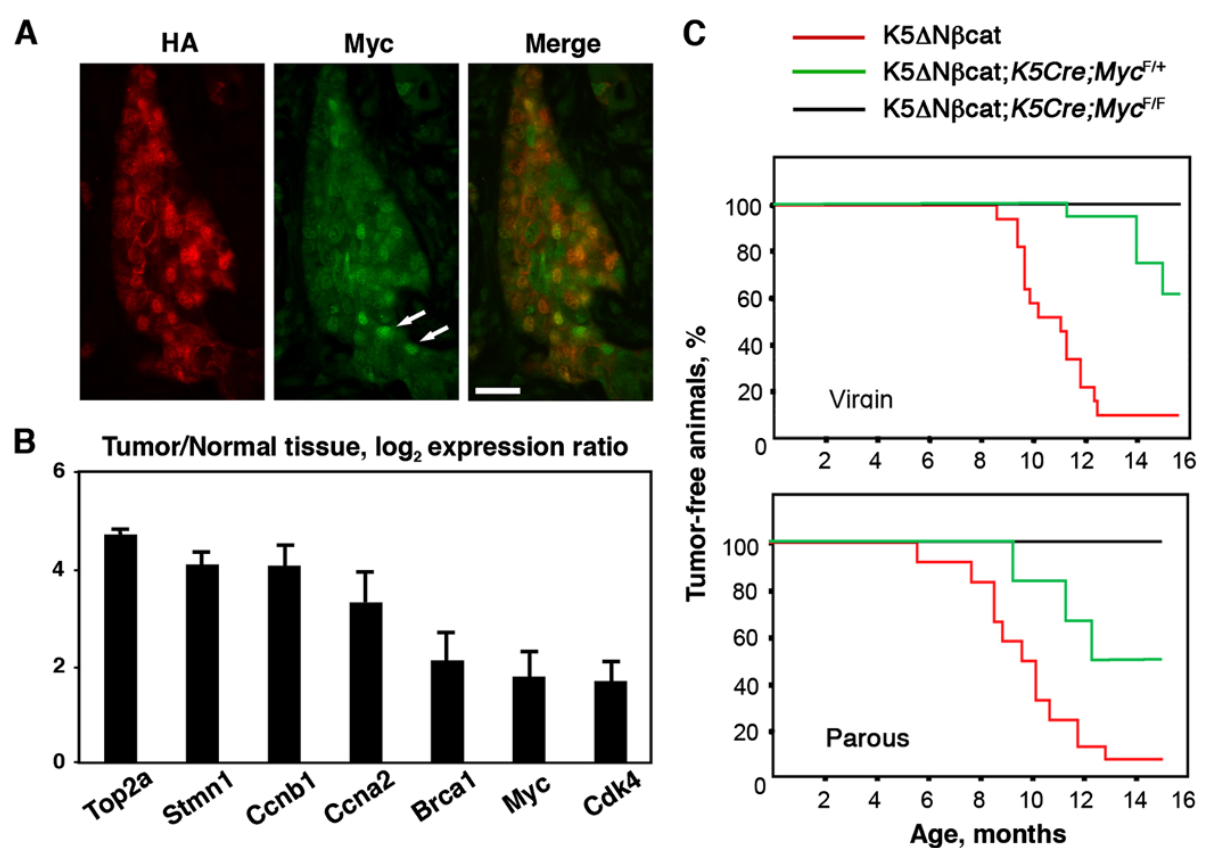

Figure $\mathbf{2}$ Myc is necessary for mammary tumor formation in $\mathbf{K} 5 \Delta \mathbf{N} \beta$ cat animals. A. Double immunofluorescence analysis of a $\mathrm{K} 5 \Delta \mathrm{N} \beta c a t$ tumor with anti-HA (red), and anti-Myc (green) antibodies. Arrows indicate the presence of nuclei positively stained for Myc. Bar: $40 \mu \mathrm{m}$. B. qPCR analysis of Myc target genes. The graph shows mean \pm SEM for four control tissue and five K5 $\Delta$ N $\beta$ cat tumor samples; $p<0.05$. $\mathbf{C}$. Kaplan-Meier

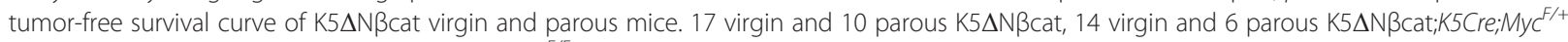

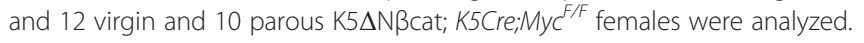


Table 1 Tumor incidence in $\mathrm{K} 5 \Delta \mathrm{N} \beta$ cat and $\mathrm{K} 55 \Delta \mathrm{N} \beta$ cat; K5Cre; $\mathrm{Myc}^{\mathrm{F} / W+}$ mice

\begin{tabular}{lll}
\hline Genotype & K5 $\Delta \mathbf{N} \beta \mathbf{c a t}$ & $\begin{array}{l}\text { K5 } \Delta \mathbf{N} \beta \mathbf{c a t} ; \\
\text { K5Cre; } \mathbf{M y c}^{\text {F/+ }}\end{array}$ \\
\hline Animals with tumor/total animals & $25 / 29$ & $8 / 20$ \\
Animals with 2 or more tumors & 16 & 2 \\
\hline
\end{tabular}

Animals were sacrificed at the age of 16 months.

\section{Stem/progenitor cell amplification induced by $\beta$-catenin} signaling is mediated by Myc

As described previously, the mammary lesions observed in $\mathrm{K} 5 \Delta \mathrm{N} \beta$ cat females consist essentially of basal epithelial cells that lack myoepithelial differentiation [23]. We hypothesize that these lesions might result from an amplification of stem/progenitor cells in the mammary basal cell layer, due to Wnt/ $\beta$-catenin signaling involving Myc activation. To investigate changes in stem cell activity in mutant mice, we isolated basal cells from 10month-old virgin control, $\mathrm{K} 5 \Delta \mathrm{N} \beta$ cat and $\mathrm{K} 5 \Delta \mathrm{N}$ ßcat; K5Cre; $M y c^{F / F}$ females using flow cytometry cell sorting. Only $\mathrm{K} 5 \Delta \mathrm{N} \beta$ cat females with no palpable mammary tumors were chosen for these experiments. Whole-mount analysis revealed mild to moderate hyperplasia in most $\mathrm{K} 5 \Delta \mathrm{N}$ ßcat mouse glands at this age (Figure 3A). Although the CD24 expression was up regulated in the basal cell population of $\mathrm{K} 5 \Delta \mathrm{N}$ ßcat mouse glands, two epithelial cell populations - luminal $\left(\mathrm{CD}_{2} 4^{+} /\right.$ CD49f $\left.{ }^{\text {low }}\right)$ and basal $\left(\mathrm{CD} 24^{+} / \mathrm{CD} 49 \mathrm{f}^{\text {high }}\right)$ - were efficiently separated (Figure $3 \mathrm{~B}$ ). We checked the purity of populations by qPCR analyses of K14 and K18 (basal and luminal keratins, respectively) in the sorted populations (Additional file 4: Figure S4). Analysis of gene expression confirmed the deletion of $M y c$ from the basal cell population of $\mathrm{K} 5 \Delta \mathrm{N} \beta \mathrm{cat}$; K5Cre; $M y c^{F /}$ mice (Figure 3C).

Basal cells accounted for $37.8 \pm 6 \%$ of the total mammary epithelial cell population in control mice and $53.4 \pm$ $3.5 \%$ in $\mathrm{K} 5 \Delta \mathrm{N}$ ßcat mice, indicating an amplification of the basal cell compartment induced by the activation of $\beta$-catenin signaling (Figure 3D). By contrast, in mutants presenting $M y c$ deletion from the basal cell layer, $\mathrm{K} 5 \Delta \mathrm{N}$ Bcat; $\mathrm{K} 5 \mathrm{Cre}$; $\mathrm{Myc}^{\mathrm{F} / \mathrm{F}}$ mice, the mammary basal compartment was smaller, accounting for only $23.4 \pm 1.5 \%$ of the total mammary epithelial cells population (Figure 3D).

To analyze the mammary stem/progenitor population, sorted basal cells were first tested in two-dimensional colony-formation assays [15]. The number of colonyforming cells was 1.8 times higher in $\mathrm{K} 5 \Delta \mathrm{N} \beta$ cat females than in controls (Figure 4A). The colonies displayed higher levels of cell proliferation, as determined by BrdU incorporation analysis, the percentage of BrdU-positive

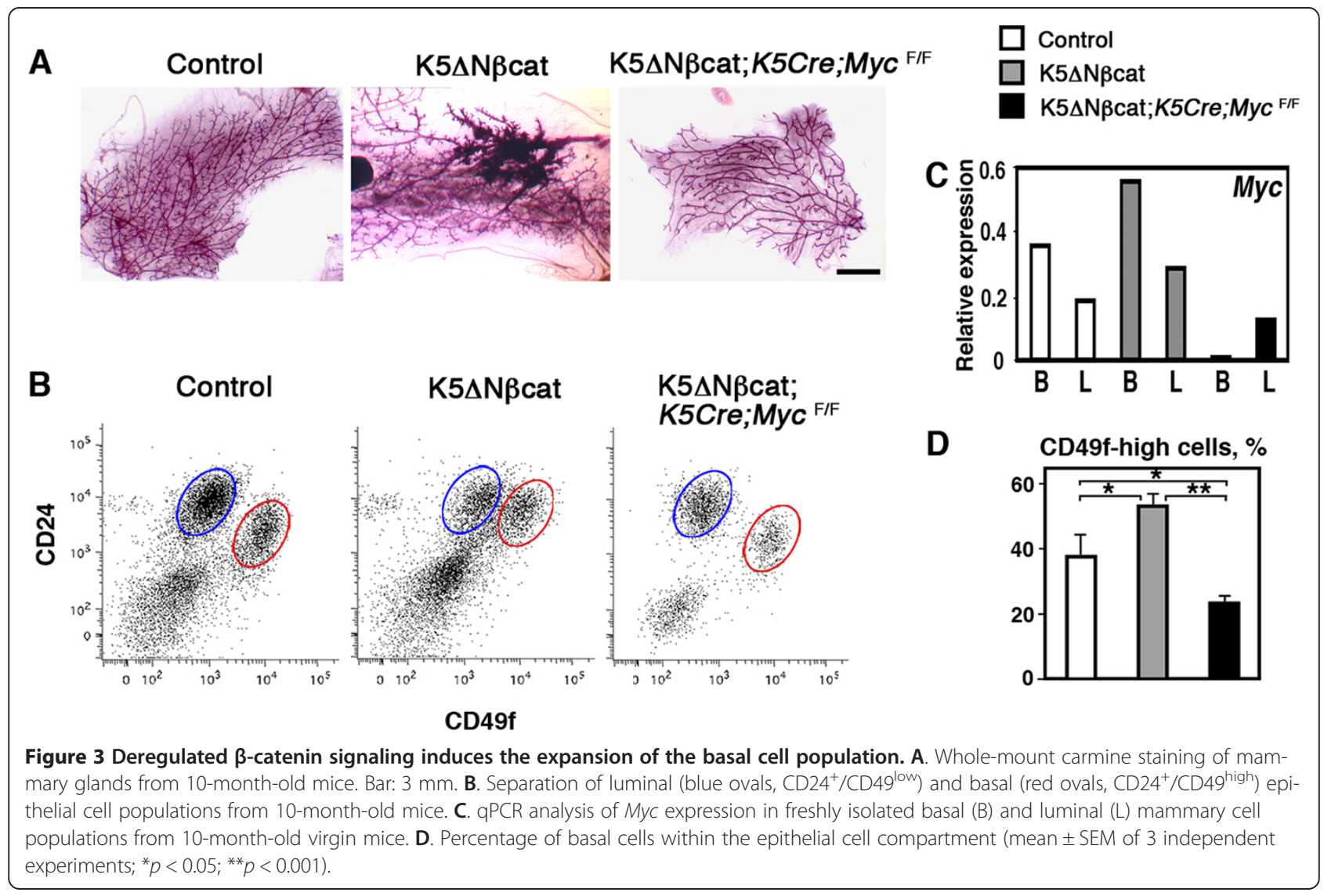




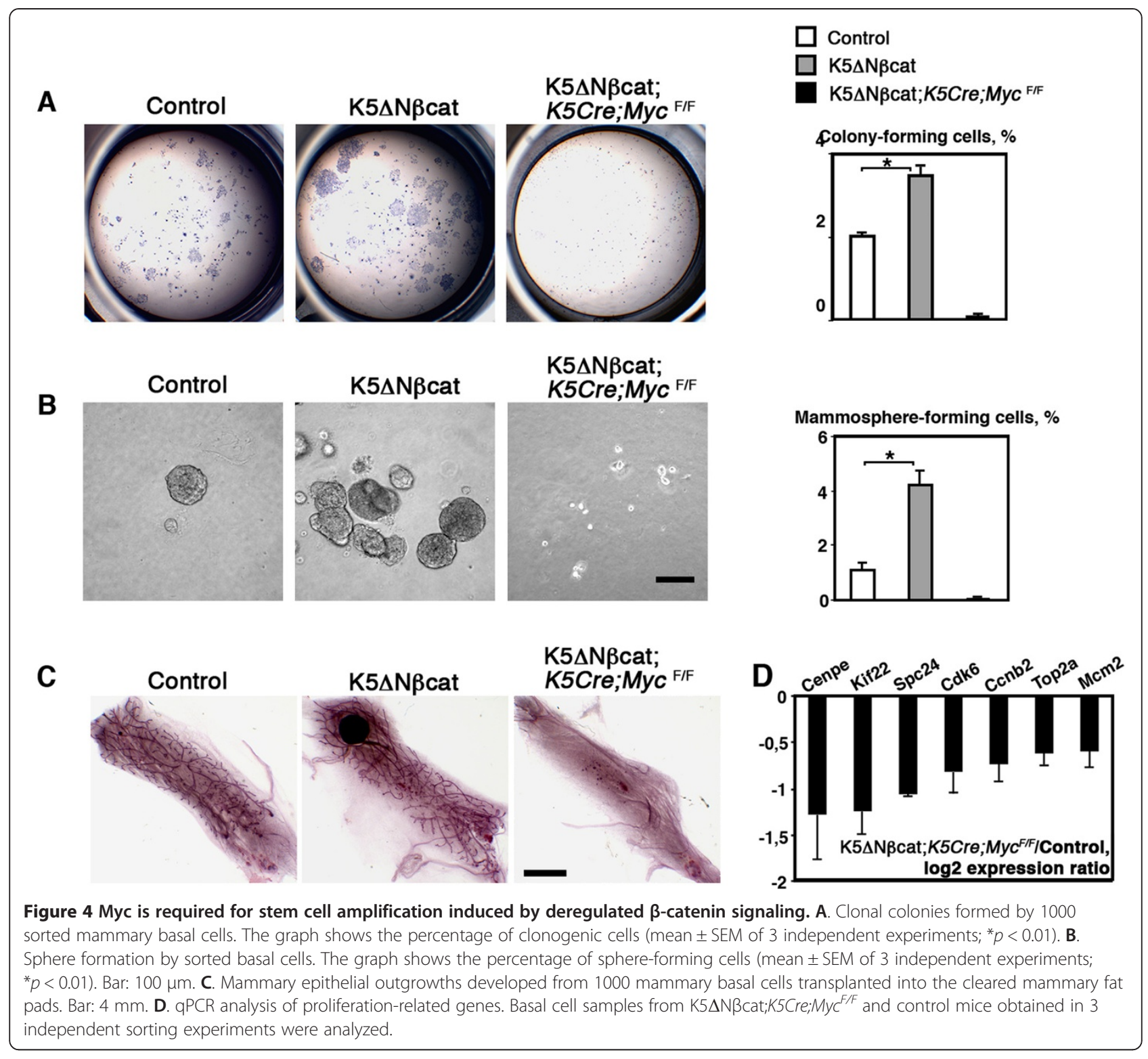

cells being $16.35 \pm 0.4$ for control cells and $23.6 \pm 1.1$ for $\mathrm{K} 5 \Delta \mathrm{N}$ pcat cells $(p<0.03$; data from three independent cell sorting experiments). Basal cells isolated from $\mathrm{K} 5 \Delta \mathrm{N}$ $\beta$ cat; $K 5 \mathrm{Cre}$; $M y c^{F / F}$ females were unable to form colonies (Figure 4A).

Sorted mammary epithelial cells have been reported to form mammospheres when cultured in the presence of $2 \%$ Matrigel, a property attributed to stem and progenitor cells [27]. As shown in Figure $4 \mathrm{~B}, \mathrm{~K} 5 \Delta \mathrm{N}$ ßcat basal cells formed four times more mammospheres than control cells, and the absence of Myc completely prevented mammosphere formation.

To further analyze the mammary stem/progenitor cell activity in mutant mice we transplanted sorted mammary basal cells at limiting dilutions (from 500 to 10 cells) into the cleared fat pad of prepubertal mice
(Table 2). In all cases, basal cells from $\mathrm{K} 5 \Delta \mathrm{N} \beta$ cat glands produced normal mammary outgrowths with no tumor development (Figure 4C). The repopulating unit frequency of the basal population was $1 / 66(1 / 134-1 / 32)$ for controls and 1/14 (1/23-1/8) for mutants (Table 2).

Table 2 Limiting dilution transplantation of mammary basal cells from control and $\mathrm{K} 5 \Delta \mathrm{N} \beta$ cat mice

\begin{tabular}{lll}
\hline Number of transplanted cells & Control & K5 $\Delta \mathbf{N} \beta \mathbf{c a t}$ \\
\hline 500 & $3 / 3$ & $3 / 3$ \\
100 & $3 / 4$ & $4 / 4$ \\
20 & $3 / 12$ & $10 / 12$ \\
10 & $3 / 11$ & $5 / 11$ \\
\hline
\end{tabular}

Repopulating unit frequency in the basal cell population, as determined in limiting dilution transplantations: 1/66 (1/134-1/32) for control and 1/14 (1/23$1 / 8)$ for $\mathrm{K} 5 \Delta \mathrm{N} \beta c a t ; 95 \% \mathrm{Cl}, p$ value $=0.000284$. 
Thus, the activation of $\beta$-catenin signaling increased the frequency of functional stem cells in the mammary basal cell layer by a factor of five. Basal cells from $K 5 \Delta \mathrm{N} \beta$ cat; K5Cre; $\mathrm{Myc}^{\mathrm{F} / F}$ mice generated no mammary outgrowths upon transplantation even, when 2000 cells were transplanted (Figure 4C).

We recently showed that $M y c$ deletion from the mammary basal cell layer affects stem cell activity [22]. Consistent with data for other tissues $[7,28]$ microarray analysis of $M y c$-deficient mammary basal cells showed impaired expression of numerous genes involved in important cell functions, including metabolism, replication, protein synthesis and the cell cycle, relating to the capacity of the cell to proliferate (Additional file 5: Table S1). Many of these genes were deregulated in the mammary tumors developed by $K 5 \Delta \mathrm{N} \beta$ cat mice (Additional file 6: Table S2). Interestingly, about half of these genes (40 out of 85 ) were found to be upregulated in the basal-like human breast tumors [26], (Additional file 6: Table S2). The expression of a set of proliferation-related genes upregulated in $\mathrm{K} 5 \Delta \mathrm{N} \beta$ cat tumors was analyzed by $\mathrm{qPCR}$ in mammary basal cells from $K 5 \Delta \mathrm{N} \beta$ cat;K5Cre;Myc ${ }^{F / F}$ mice and control basal cells. In the absence of Myc, these genes were downregulated (Figure 4D), suggesting that $M y c$ deletion impeded $\beta$-catenin-induced tumorigenesis, probably by restricting the acute growth program required for the amplification of basal progenitors and tumor formation.

\section{Discussion}

We show here that constitutive stimulation of $\beta$-catenin signaling in the mammary basal cell layer of transgenic mice, led to development of triple-negative tumors that required activation of the Myc pathway. These tumors displayed transcriptional profile resembling that of human breast basal-like carcinomas and presented morphological similarities with metaplastic breast carcinomas, a basal-like tumor subtype [6].

Notably, K5 $\Delta \mathrm{N} \beta$ cat mammary tumors are different from those developing in MMTV- $\Delta$ N89 $\beta$ cat and MMTV-Wnt1 mice suggesting different cellular and molecular mechanisms underlying tumorigenesis. In MMTV- $\Delta$ N89 $\beta$ cat mice, luminal ER- tumors are thought to develop due to activation of $\beta$-catenin signaling in luminal progenitors, whereas in MMTV-Wnt1 model, "mixed" tumors containing luminal ER + and myoepithelial cells were suggested to originate from stem cells $[29,30]$. We show here that, as assessed in mammosphere and transplantation assays, in $\mathrm{K} 5 \Delta \mathrm{N} \beta$ cat mice, a basal stem/progenitor cell population is amplified at the early stages of malignancy, before the formation of basal-like invasive tumors with metaplastic characteristics.

The differences between breast tumor subgroups were hypothesized to reflect different types of mutation leading to tumorigenesis, or different cells of origin [31].
Two independent studies have indicated that basal-like Brca1-associated human and mouse mammary tumors originate from luminal epithelial progenitors [14,32]. The transformation of primary human breast basal-type epithelial cells has been reported to result in the development of metaplastic tumors [33]. Therefore, in light of our results, it is tempting to suggest that metaplastic basal-like breast tumors with squamous differentiation originate from basal progenitors or cells that acquired stem/progenitor properties due to enhanced $\beta$-catenin signaling. Of note, mammary lesions developed in $\mathrm{K} 5 \Delta \mathrm{N} \beta$ cat mice, consist of tumor cells that, in contrast to basal myoepithelial cells, do not express SM markers, suggesting that $\beta$-catenin activation either prevented SM differentiation of undifferentiated progenitors, or induced dedifferentiation of myoepithelial cell and acquisition of a progenitor phenotype, resulting in accumulation of basal cells with stem/progenitor properties. Transition between non-stem and stem-like states has been described in cultured human mammary basal epithelial cells [34]. Moreover, enhanced Wnt signaling in the intestinal epithelium has been found to induce dedifferentiation of non-stem cells and acquisition of tumor-initiating capacity [35]. Further studies involving the use of genetic markers of differentiated myopithelial cells are required to identify within the mammary basal compartment, the cell at the origin of $\mathrm{K} 5 \Delta \mathrm{N} \beta$ cat mouse tumors.

Genes encoding Myc and CyclinD1, two important Wnt targets, are often amplified and/or up-regulated in breast cancer [36]. Confirming previous analysis of preneoplasic glands [23], we have not found a significant up-regulation of Cyclin D1 in $\mathrm{K} 5 \Delta \mathrm{N} \beta$ cat tumors. This result is in agreement with previous studies reporting that Cyclin D1 is dispensable for Wnt or $\beta$-catenin induced tumorigenesis $[37,38]$. In $\mathrm{K} 5 \Delta \mathrm{N} \beta$ cat mammary tumors, similarly to previous findings in intestinal tumor models [39], Myc pathway appears activated and indispensable for $\beta$-catenin induced tumorigenesis. Interestingly, different studies have identified a Myc transcriptional gene signature to be associated with the basal-like breast cancer subtype [9-11]. In addition, Myc signaling has been shown to be upregulated in high-grade mammary tumors with presumptive cancer stem cell properties $[40,41]$. Therefore, Myc-targeting therapies are thought to be promising for specific treatment of different breast tumors [42]. The direct Myc inhibition seems difficult, and strategies used to target Myc include approaches focused on tumor cell metabolic abnormalities induced by Myc overexpression [43] or synthetic-lethal strategy $[10,44]$. A recent study has shown that cyclin-dependent kinase inhibition leads to regression of triple-negative tumors with Myc activation [10].

We have recently shown that $\mathrm{Myc}$ is essential for mammary stem cell activity [22]. In agreement with previous reports [7], microarray analysis of Myc deficient 
basal cells shows an impaired expression of numerous genes involved in essential cell functions converging on the capacity of the cell to proliferate. An important part of these genes are upregulated in the $\mathrm{K} 5 \Delta \mathrm{N} \beta \mathrm{cat}$ mammary tumors. Thus, our results indicate that Myc acts as the ultimate downstream effecter of $\beta$-catenin to provide the enhanced proliferative capacity to basal stem/progenitor cells leading to their amplification and tumorigenesis and preventing the myoepithelial differentiation (Figure 5). One important question to address in future studies is whether Myc deletion from established $\mathrm{K} 5 \Delta \mathrm{N} \beta \mathrm{cat}$ tumors would lead to tumor regression. Such experiments would require inducible promoters permitting efficient gene deletion at desired time points.

In conclusion, our work provides new insights into the possible contribution of stem/progenitor cells to breast tumorigenesis and further confirms that the Myc pathway can be an interesting target for the development of basal-like breast cancer-tailored therapies.

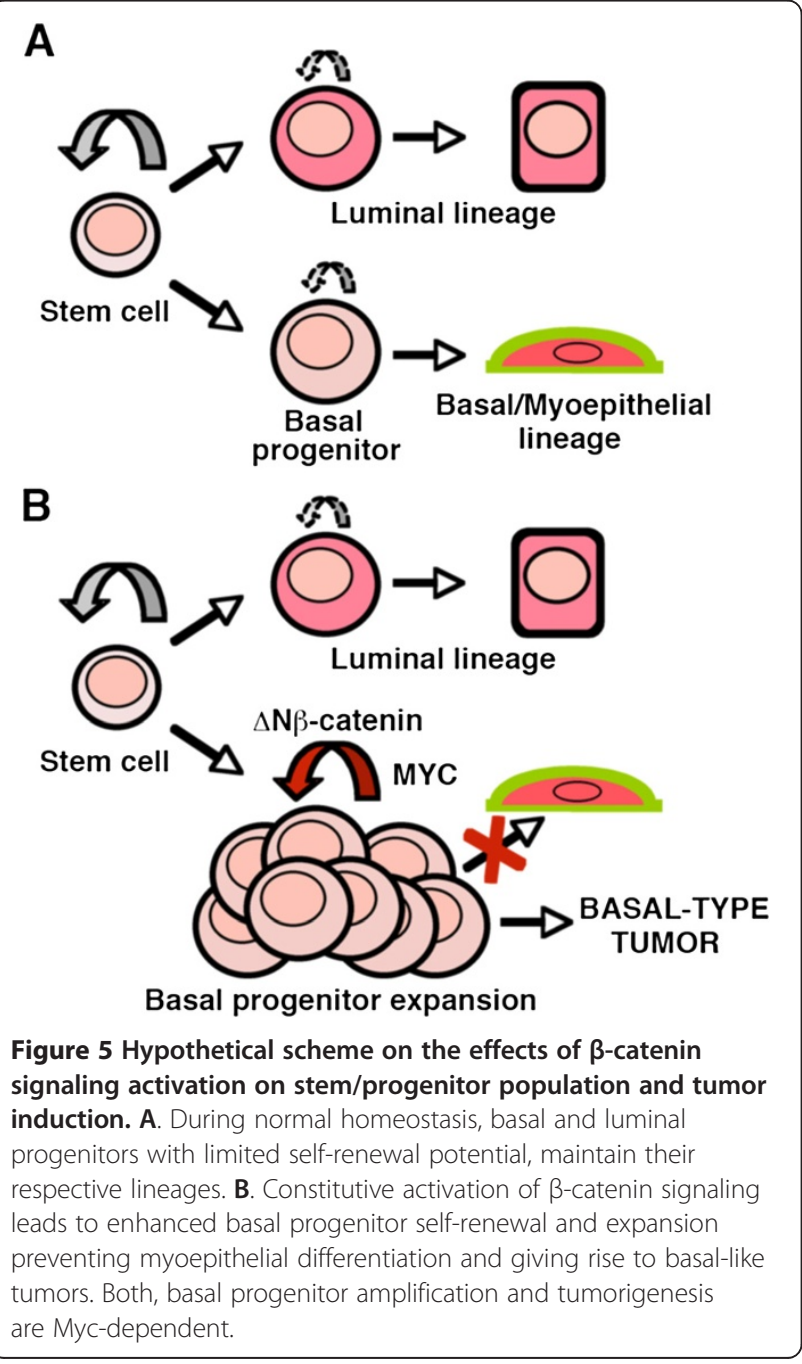

\section{Methods}

Mice

K5 $\Delta \mathrm{N} \beta$ cat, $K 5 \mathrm{Cre}$ and $M y c^{F / F}$ mice have been previously described [22,23,45-47]. All mice were bred in a 129SV/ C57BL6 genetic background. Experiments were conducted in accordance with French veterinary guidelines and those of the Council of Europe for animal experimentation (L358-86/609EEC).

\section{Microarray analysis}

Total RNA was extracted from mammary tissue with Trizol Reagent (Invitrogen), treated with DNAse and cleaned up on RNAeasy microcolumns (Qiagen). RNA was isolated from sorted basal cells in three independent biological pools of four to six control or mutant mice with the RNAeasy Microkit (Qiagen). Quality control was performed with an Agilent 2100 Bioanalyzer and the RNA 6000 Pico total RNA Kit (Agilent Technologies). As previously described [48], the WT-Ovation ${ }^{\mathrm{TM}}$ Pico RNA Amplification System and FL- Ovation ${ }^{\mathrm{TM}}$ cDNA Biotin Module V2 (Nugen) were applied to $1 \mathrm{ng}$ of total RNA from sorted cells to generate biotinylated cDNA. Microarray analysis was carried out with Affymetrix GeneChip Mouse Genome 4302.0 arrays. Expression data were normalized with the MicroArray Suite v.5.0 (MAS 5.0) algorithm and analyzed with the Partek Genomics Suite (Partek Incorporated). Differences in gene expression were considered to be validated whenever, for each ratio, the higher median gene expression value was up to 30 (corresponding to the estimated background cutoff, data not shown) and the corresponding fold-change was greater than 2 . The microarray data have been deposited in the NCBI Gene Expression Omnibus and are accessible through GEO Series accession number GSE43825 (http://www.ncbi.nlm.nih.gov/geo/query/acc.cgi?token=rn cxjwmcegeiuhw\&acc=GSE43825).

\section{Clustering analysis}

Hierarchical clustering analysis was carried out with Partek Genomics Suite Software (Partek, Inc.). The molecular and functional interactions of the genes identified were also analyzed with Ingenuity pathways analysis (IPA) tools (Ingenuity ${ }^{\circ}$ Systems) and a gene ontology approach (http:// david.abcc.ncifcrf.gov). To compare the mouse and the human datasets, after GCRAMA normalization with Partek, a common correspondence between the mouse and human genes, was performed by using the annotation Tools package 2.35-8 in R 2.11.1 software and the HomoloGene database (ftp://ftp.ncbi.nlm.nih.gov/pub/HomoloGene).

\section{qPCR analysis}

RNA was reverse-transcribed with MMLV $\mathrm{H}(-)$ Point reverse transcriptase (Promega), and quantitative PCR was performed by real-time monitoring of the increase 
in SYBR Green fluorescence on an ABI PRISM 7900HT Sequence Detection System (Applied Biosystems). The values obtained were normalized to Gapdh levels. The primers used for qPCR analysis are listed in Additional file 7: Table S3.

\section{Preparation of mammary epithelial cells and cell sorting analysis}

The inguinal mammary glands of four to five females or hyperplastic mammary samples from two $K 5 \Delta \mathrm{N} \beta c$ at females were pooled for the preparation of single-cell suspensions and cells were processed for flow cytometry as previously described $[16,49]$. The following conjugated antibodies were used: anti-CD24-PE (clone M1/69; BD Pharmingen), anti-CD49f-FITC (clone GoH3; BD Pharmingen), anti-CD45-APC (clone 30-F11; Biolegend), antiCD31-APC (clone MEC13.3; Biolegend). Labeled cells were analyzed and sorted on a FACSVantage flow cytometer (Becton Dickinson, San Jose, CA, USA). Sorted cell populations were routinely reanalyzed and found to be 94 to $98 \%$ pure. Cell viability after sorting, as estimated by trypan blue exclusion, was between 80 and $90 \%$.

\section{Transplantation assays}

Sorted basal cells were resuspended in $10 \mu$ of $50 \%$ growth factor-reduced Matrigel (BD Bioscience) and injected into the inguinal fat pads of three-week-old nude Balb/c females cleared of endogenous epithelium, as described elsewhere [49]. Mutant and control cells were grafted into contralateral fat pads of the same recipient mouse and outgrowths were analyzed 10 weeks after transplantation. Repopulating unit frequency was calculated with Extreme Limiting Dilution Analysis software [50].

\section{Cell culture assays}

Sorted basal cells were cultured in DMEM/F12 medium containing 1\% FCS and B27 supplement, at a density of 1000 cells per well [15]. For suspension sphere culture, sorted basal cells were plated on 24-well ultralowattachment plates at 5000 cells/well and cultured in DMEM/F12 media containing B27, EGF, bFGF, heparin and $2 \%$ growth factor-reduced Matrigel (BD Bioscience, [27]. ImageJ software was used for quantification.

\section{Whole-mount analyses, histology and immunolabeling}

Dissected mammary fat pads were spread onto glass slides, fixed in a 1/3/6 mixture of acetic acid/chloroform/methanol and stained with carmine (whole-mount staining). For histological analysis, samples were embedded in paraffin. Sections (7 $\mu \mathrm{m}$ thick) were cut and dewaxed for haematoxylin/eosin staining or immunolabeling, as previously described [23]. The following primary antibodies were used: mouse monoclonal anti- $\alpha$-smooth muscle actin,
anti-K14 (Sigma), anti-K8 (Covance) and anti-oestrogen receptor $\alpha$ (Dako); rat monoclonal anti-HA (Roche); rabbit monoclonal anti-calponin (Epitomics), polyclonal anti-K5, (Covance), anti-Ki67 (Novocastra), anti-c-erbB2, anti cMyc and anti-PR (sc-284, sc-764 and sc-7208, respectively, Santa Cruz Biotechnologies). Alexafluor-conjugated secondary antibodies (1/1000, Molecular Probes) were used for immunofluorescence labelling. The Envision + System HRP kit (Dako) was used for immunohistochemistry.

\section{Statistical analysis of the data}

All values are shown as mean \pm standard error of the mean (SEM). P values were determined using Student's test with two-tailed distribution and unequal variance.

\section{Additional files}

Additional file 1: Figure S1. Immunohistological analysis of $K 5 \Delta N \beta c$ at mammary tumors. A. Double immunofluorescence with antibodies against: K14 (red) and calponin (green) left panel; K5 (red) and K8 (green), central panel; HA (red) and Ki67 (green), right panel. B.

Immunohistochemistry with the antibody against ErbB2 in normal mammary tissue (left) and a $\mathrm{K} 5 \Delta \mathrm{N} \beta$ cat hyperplasia (right). Bar: $75 \mu \mathrm{m}$ (A), $150 \mu \mathrm{m}$ (B).

Additional file 2: Figure S2. Unsupervised hierarchical clustering of $\mathrm{K} 5 \Delta \mathrm{N} \beta$ cat tumor data with a dataset obtained from human breast cancer cell lines (A, ref. [25]) and breast tumors (B, Ref. [26]).

Additional file 3: Figure S3. Gene expression analysis of $\mathrm{K} 5 \Delta \mathrm{N} \beta \mathrm{cat}$ mammary tumors. A. Q-PCR analysis of Wnt/ $\beta$-catenin pathway targets. The graph represent the mean values \pm S.E.M. of four control tissue and five $\mathrm{K} 5 \Delta \mathrm{N} \beta$ cat tumor samples; $p<0.05$. B. Ingenuity pathway analysis (IPA) of Myc pathway in $\mathrm{K} 5 \Delta \mathrm{N} \beta$ cat mammary tumors. The genes whose expression is increased in tumors with respect to normal mammary tissue are shown in red, and those whose expression is decreased, in green.

Additional file 4: Figure S4. Q-PCR analysis of Krt14, and Krt18 in freshly isolated basal $(B)$ and luminal $(L)$ cell populations from ten monthold virgin control, $\mathrm{K} 5 \Delta \mathrm{N} \beta \mathrm{cat}$ and $\mathrm{K} 5 \Delta \mathrm{N} \beta \mathrm{cat} ; \mathrm{K} 5 \mathrm{Cre}, \mathrm{Myc} \mathrm{C}^{\mathrm{F} / \mathrm{F}}$ mouse mammary glands (the cell sorting experiment shown in Figure $3 \mathrm{~B}$ ).

Additional file 5: Table S1. GOstat analysis of genes downregulated in Myc-deficient basal cells.

Additional file 6: Table S2. GO analysis of the genes downregulated in Myc-deficient basal cells and upregulated in $\mathrm{K} 5 \Delta \mathrm{N} \beta$ cat hyperplasia.

Additional file 7: Table S3. Primers used for $\mathrm{qPCR}$ analysis.

\section{Competing interests}

The authors declare that they have no competing interests.

\section{Authors' contributions}

$M M F, M M, A C, M A D$ and VP performed experiments and analysed data, CD performed bioinformatic analyses of the microarray data, AG and MAD shared expertise, MAG and MMF designed the experimental plan and wrote the manuscript. All authors contributed to data analysis and interpretation and final approval of the manuscript. MMF and MAG contributed equally to this work.

\section{Acknowledgements}

We are particularly grateful to A. Di Cicco, D. Gentien, W. Richer and C. Laurent for expert technical assistance, to Dr. I. Grandjean and the personnel of the animal facilities at Institut Curie for taking care of the mice and to Z . Maciorowski and A. Viguier for excellent assistance with FACS analyses. We also thank Dr. J.L. Jorcano and I.M. de Alboran for providing mouse strains and Dr. D. Medina for valuable discussions. The work was supported by La Ligue Nationale Contre le Cancer (Equipe Labelisée 2009, 2013) and a grant 
from Agence Nationale de la Recherche ANR-08-BLAN-0078-01 to MAG. MM, $A C$ and $A G$ received funding from Association pour la Recherche sur le Cancer; AC, from Institut Curie and Servier Laboratories; AG from the Instituto de Salud Carlos III (Spain), PI11/02070; CD is Ingénieur de Recherche at the Centre National de la Recherche Scientifique (CNRS); MAG is Directeur de Recherche, MMF, MAD and AG are Chargé de Recherche at the Institut National de la Santé et de la Recherche Médicale (INSERM).

\section{Author details}

'Institut Curie, Centre de Recherche, F-75248 Paris, France. ${ }^{2}$ CNRS, UMR144, F-75248 Paris, France. ${ }^{3}$ Translational Research Department, Institut Curie, F-75248 Paris, France. ${ }^{4}$ Fundación Marqués de Valdecilla-IFIMAV, 39008 Santander, Spain. ${ }^{5}$ Inserm ADR Languedoc - Roussillon, F-34093 Montpellier, France.

Received: 25 July 2013 Accepted: 23 October 2013

Published: 30 October 2013

\section{References}

1. Bertucci F, Finetti P, Birnbaum D: Basal breast cancer: a complex and deadly molecular subtype. Curr Mol Med 2012, 12:96-110.

2. Reis-Filho JS, Pusztai L: Gene expression profiling in breast cancer: classification, prognostication, and prediction. Lancet 2011, 378:1812-1823.

3. Sorlie T, Perou CM, Tibshirani R, Aas T, Geisler S, Johnsen H, Hastie T, Eisen MB, van de Rijn M, Jeffrey SS, et al: Gene expression patterns of breast carcinomas distinguish tumor subclasses with clinical implications. Proc Nat Acad Sci USA 2001, 98:10869-10874.

4. Prat A, Parker JS, Karginova O, Fan C, Livasy C, Herschkowitz Jl, He X, Perou CM: Phenotypic and molecular characterization of the claudin-low intrinsic subtype of breast cancer. Breast Cancer Res 2010, 12:R68.

5. Farmer $\mathrm{P}$, Bonnefoi $\mathrm{H}$, Becette $\mathrm{V}$, Tubiana-Hulin $\mathrm{M}$, Fumoleau $\mathrm{P}$, Larsimont $\mathrm{D}$, Macgrogan G, Bergh J, Cameron D, Goldstein D, et al: Identification of molecular apocrine breast tumours by microarray analysis. Oncogene 2005, 24:4660-4671.

6. Weigelt B, Kreike B, Reis-Filho JS: Metaplastic breast carcinomas are basallike breast cancers: a genomic profiling analysis. Breast Cancer Res Treat 2009, 117:273-280

7. Eilers M, Eisenman RN: Myc's broad reach. Genes Dev 2008, 22:2755-2766.

8. Xu J, Chen Y, Olopade Ol: MYC and breast cancer. Genes Cancer 2010 1:629-640

9. Alles MC, Gardiner-Garden M, Nott DJ, Wang Y, Foekens JA, Sutherland RL, Musgrove EA, Ormandy CJ: Meta-analysis and gene set enrichment relative to er status reveal elevated activity of MYC and E2F in the "basal" breast cancer subgroup. PLoS One 2009, 4:e4710.

10. Horiuchi D, Kusdra L, Huskey NE, Chandriani S, Lenburg ME, Gonzalez-Angulo AM, Creasman KJ, Bazarov AV, Smyth JW, Davis SE, et al: MYC pathway activation in triple-negative breast cancer is synthetic lethal with CDK inhibition. J Exp Med 2012, 209:679-696.

11. Kim J, Woo AJ, Chu J, Snow JW, Fujiwara Y, Kim CG, Cantor AB, Orkin SH: A Myc network accounts for similarities between embryonic stem and cancer cell transcription programs. Cell 2010, 143:313-324

12. DiMeo TA, Anderson K, Phadke P, Fan C, Perou CM, Naber S, Kuperwasser C: A novel lung metastasis signature links Wnt signaling with cancer cell self-renewal and epithelial-mesenchymal transition in basal-like breast cancer. Cancer Res 2009, 69:5364-5373.

13. Khramtsov Al, Khramtsova GF, Tretiakova M, Huo D, Olopade Ol, Goss KH: Wnt/beta-catenin pathway activation is enriched in basal-like breast cancers and predicts poor outcome. Am J Pathol 2010, 176:2911-2920.

14. Lim E, Vaillant F, Wu D, Forrest NC, Pal B, Hart AH, Asselin-Labat ML, Gyorki DE, Ward T, Partanen A, et al: Aberrant luminal progenitors as the candidate target population for basal tumor development in BRCA1 mutation carriers. Nat Med 2009, 15:907-913.

15. Shackleton M, Vaillant F, Simpson K, Stingl J, Smyth GK, Asselin-Labat ML, Wu L, Lindeman GJ, Visvader JE: Generation of a functional mammary gland from a single stem cell. Nature 2006, 439:84-88.

16. Stingl J, Eirew P, Ricketson I, Shackleton M, Vaillant F, Choi D, Li HI, Eaves CJ: Purification and unique properties of mammary epithelial stem cells. Nature 2006, 439:993-997.

17. van Amerongen R, Bowman AN, Nusse R: Developmental stage and time dictate the fate of Wnt/beta-catenin-responsive stem cells in the mammary gland. Cell Stem Cell 2012, 11:387-400.
18. Van Keymeulen A, Rocha AS, Ousset M, Beck B, Bouvencourt G, Rock J, Sharma N, Dekoninck S, Blanpain C: Distinct stem cells contribute to mammary gland development and maintenance. Nature 2011, 479:189-193.

19. Zeng YA, Nusse R: Wnt proteins are self-renewal factors for mammary stem cells and promote their long-term expansion in culture. Cell Stem Cell 2010, 6:568-577.

20. Korkaya H, Paulson A, Charafe-Jauffret E, Ginestier C, Brown M, Dutcher J, Clouthier SG, Wicha MS: Regulation of mammary stem/progenitor cells by PTEN/Akt/beta-catenin signaling. PLOS Biol 2009, 7:e1000121.

21. Plaks V, Brenot A, Lawson DA, Linnemann JR, Van Kappel EC, Wong KC, de Sauvage F, Klein OD, Werb Z: Lgr5-expressing cells are sufficient and necessary for postnatal mammary gland organogenesis. Cell Rep 2013, 3:70-78.

22. Moumen M, Chiche A, Deugnier MA, Petit V, Gandarillas A, Glukhova MA, Faraldo MM: The proto-oncogene Myc is essential for mammary stem cell function. Stem Cells 2012, 30:1246-1254

23. Teuliere J, Faraldo MM, Deugnier MA, Shtutman M, Ben-Ze'ev A, Thiery JP, Glukhova MA: Targeted activation of beta-catenin signaling in basal mammary epithelial cells affects mammary development and leads to hyperplasia. Development 2005, 132:267-277.

24. Herschkowitz Jl, Simin K, Weigman VJ, Mikaelian I, Usary J, Hu Z, Rasmussen KE, Jones LP, Assefnia S, Chandrasekharan S, et al: Identification of conserved gene expression features between murine mammary carcinoma models and human breast tumors. Genome Biol 2007, 8:R76.

25. Neve RM, Chin K, Fridlyand J, Yeh J, Baehner FL, Fevr T, Clark L, Bayani N, Coppe JP, Tong F, et al: A collection of breast cancer cell lines for the study of functionally distinct cancer subtypes. Cancer Cell 2006, 10:515-527.

26. Bertucci $F$, Finetti $P$, Cervera N, Charafe-Jauffret E, Buttarelli M, Jacquemier J, Chaffanet M, Maraninchi D, Viens P, Birnbaum D: How different are luminal a and basal breast cancers? Int J Cancer 2009, 124:1338-1348.

27. Spike BT, Engle DD, Lin JC, Cheung SK, La J, Wahl GM: A mammary stem cell population identified and characterized in late embryogenesis reveals similarities to human breast cancer. Cell Stem Cell 2012, 10:183-197.

28. Soucek L, Evan Gl: The ups and downs of Myc biology. Curr Opin Genet Dev 2010, 20:91-95.

29. Li Y, Welm B, Podsypanina K, Huang S, Chamorro M, Zhang X, Rowlands T, Egeblad M, Cowin P, Werb Z, et al: Evidence that transgenes encoding components of the Wnt signaling pathway preferentially induce mammary cancers from progenitor cells. Proc Natl Acad Sci USA 2003, 100:15853-15858.

30. Teissedre B, Pinderhughes A, Incassati A, Hatsell SJ, Hiremath M, Cowin P: MMTV-Wnt1 and -DeltaN89beta-catenin induce canonical signaling in distinct progenitors and differentially activate Hedgehog signaling within mammary tumors. PLoS One 2009, 4:e4537.

31. Visvader JE: Cells of origin in cancer. Nature 2011, 469:314-322.

32. Molyneux G, Geyer FC, Magnay FA, McCarthy A, Kendrick H, Natrajan R, Mackay A, Grigoriadis A, Tutt A, Ashworth A, et al: BRCA1 basal-like breast cancers originate from luminal epithelial progenitors and not from basal stem cells. Cell Stem Cell 2010, 7:403-417.

33. Keller PJ, Arendt LM, Skibinski A, Logvinenko T, Klebba I, Dong S, Smith AE, Prat A, Perou CM, Gilmore H, et al: Defining the cellular precursors to human breast cancer. Proc Natl Acad Sci USA 2012, 109:2772-2777.

34. Chaffer CL, Brueckmann I, Scheel C, Kaestli AJ, Wiggins PA, Rodrigues LO, Brooks M, Reinhardt F, Su Y, Polyak K, et al: Normal and neoplastic nonstem cells can spontaneously convert to a stem-like state. Proc Natl Acad Sci USA 2011, 108:7950-7955.

35. Schwitalla S, Fingerle AA, Cammareri P, Nebelsiek T, Goktuna SI, Ziegler PK Canli O, Heijmans J, Huels DJ, Moreaux G, et al: Intestinal tumorigenesis initiated by dedifferentiation and acquisition of stem-cell-like properties. Cell 2013, 152:25-38

36. Incassati A, Chandramouli A, Eelkema R, Cowin P: Key signaling nodes in mammary gland development and cancer: beta-catenin. Breast Cancer Res 2010, 12:213.

37. Rowlands TM, Pechenkina IV, Hatsell SJ, Pestell RG, Cowin P: Dissecting the roles of beta-catenin and cyclin D1 during mammary development and neoplasia. Proc Natl Acad Sci USA 2003, 100:11400-11405.

38. Yu Q, Geng Y, Sicinski P: Specific protection against breast cancers by cyclin D1 ablation. Nature 2001, 411:1017-1021.

39. Sansom OJ, Meniel VS, Muncan V, Phesse TJ, Wilkins JA, Reed KR, Vass JK, Athineos D, Clevers H, Clarke AR: Myc deletion rescues Apc deficiency in the small intestine. Nature 2007, 446:676-679. 
40. Ben-Porath I, Thomson MW, Carey VJ, Ge R, Bell GW, Regev A, Weinberg RA: An embryonic stem cell-like gene expression signature in poorly differentiated aggressive human tumors. Nat Genet 2008, 40:499-507.

41. Wong DJ, Liu H, Ridky TW, Cassarino D, Segal E, Chang HY: Module map of stem cell genes guides creation of epithelial cancer stem cells. Cell Stem Cell 2008, 2:333-344.

42. Albihn A, Johnsen Jl, Henriksson MA: MYC in oncogenesis and as a target for cancer therapies. Adv Cancer Res 2010, 107:163-224.

43. Dang CV: Therapeutic targeting of Myc-reprogrammed cancer cell metabolism. Cold Spring Harb Symp Quant Biol 2011, 76:369-374.

44. Goga A, Yang D, Tward AD, Morgan DO, Bishop JM: Inhibition of CDK1 as a potential therapy for tumors over-expressing MYC. Nat Med 2007, 13:820-827.

45. de Alboran IM, O'Hagan RC, Gartner F, Malynn B, Davidson L, Rickert R, Rajewsky K, DePinho RA, Alt FW: Analysis of C-MYC function in normal cells via conditional gene-targeted mutation. Immunity 2001, 14:45-55.

46. Ramirez A, Page A, Gandarillas A, Zanet J, Pibre S, Vidal M, Tusell L, Genesca A Whitaker DA, Melton DW, Jorcano JL: A keratin K5Cre transgenic line appropriate for tissue-specific or generalized Cre-mediated recombination. Genesis 2004, 39:52-57.

47. Zanet J, Pibre S, Jacquet C, Ramirez A, de Alboran IM, Gandarillas A: Endogenous Myc controls mammalian epidermal cell size, hyperproliferation, endoreplication and stem cell amplification. J Cell Sci 2005, 118:1693-1704.

48. Clement-Ziza M, Gentien D, Lyonnet S, Thiery JP, Besmond C, Decraene C: Evaluation of methods for amplification of picogram amounts of total RNA for whole genome expression profiling. BMC Genomics 2009, 10:246.

49. Taddei I, Deugnier MA, Faraldo MM, Petit V, Bouvard D, Medina D, Fassler R, Thiery JP, Glukhova MA: Beta1 integrin deletion from the basal compartment of the mammary epithelium affects stem cells. Nat Cell Biol 2008, 10:716-722.

50. Hu Y, Smyth GK: ELDA: extreme limiting dilution analysis for comparing depleted and enriched populations in stem cell and other assays. J Immunol Methods 2009, 347:70-78.

doi:10.1186/1476-4598-12-132

Cite this article as: Moumen et al:: Myc is required for $\beta$-catenin-

mediated mammary stem cell amplification and tumorigenesis. Molecular Cancer 2013 12:132.

\section{Submit your next manuscript to BioMed Central and take full advantage of:}

- Convenient online submission

- Thorough peer review

- No space constraints or color figure charges

- Immediate publication on acceptance

- Inclusion in PubMed, CAS, Scopus and Google Scholar

- Research which is freely available for redistribution 